\title{
Pengaruh Lama Penyimpanan Terhadap Kadar Air Dan Pengurangan Bobot Tepung Pisang Gablok (Musa paradisiaca balbisiana)
}

\section{(Effect of Storage Duration on Water Content and Reduction of Gablok Banana Flour Weight (Musa paradisiaca balbisiana)}

\author{
Andi Indrawan, ${ }^{1)}$ Murtiari Eva, ${ }^{2)}$ Elly Yuniati Sani ${ }^{2)}$ \\ 1) Staf Pengajar Program Studi Seni Kuliner, AKS Ibu Kartini, Semarang, Indonesia \\ 2) Staf Pengajar Teknologi Pertanian Fakultas Teknologi Pertanian Dan Peternakan Universitas \\ Semarang \\ andi.indrawan88@gmail.com
}

\begin{abstract}
ABSTRAK
Pisang merupakan bahan pangan yang umumnya tahan lama maka perlu diubah sebagai produk lain yaitu dibuat tepung pisang. Penelitian ini bertujuan untuk mengetahui pengaruh lama penyimpanan terhadap kadar air dan pengurangan bobot tepung pisang gablok selama penyimpanan. Metode penelitian dengan menggunakan rancangan acak lengkap (RAL) yang dilanjutkan uji DMRT, lama simpan $\left(\mathrm{B}_{1} / 0\right.$ hari, $\mathrm{B}_{2} / 7$ hari, $\mathrm{B}_{3} / 14$ hari, $\mathrm{B}_{4} / 21$ hari, $\mathrm{B}_{5} / 28$ hari, $\mathrm{B}_{6} / 35$ hari dan $\mathrm{B}_{7} / 42$ hari) masing-masing perlakuan dilakukan pengulangan sebanyak dua kali. Pengamatan yang dilakukan yaitu kadar air, susut bobot tepung pisang selama penyimpanan. Hasil penelitian menunjukkan bahwa selama penyimpanan tepung pisang kepok gablok terjadi peningkatan kadar air, dan susut bobot. Pada perlakuan penggunaan jenis kemasan kain diperoleh rerata kadar air tertinggi $(9,48 \%)$, yang masih memenuhi persyaratan kadar air agar mikroba tidak tumbuh, yaitu dibawah $14-15 \%$ dan telah memenuhi standar kadar air tepung pisang menurut SNI (01-44471998).
\end{abstract}

Kata kunci: lama penyimpanan, kadar air, susut bobot, pisang gablok

\section{ABSTRACT}

Banana is a food that is generally durable so it needs to be changed as another product that is made banana flour. This study aims to determine the effect of storage time on water content and weight reduction of Gabok banana flour during storage. The research method uses a completely randomized design (CRD) followed by DMRT test, shelf life (B1 / 0 days, B2 / 7 days, B3 $/ 14$ days, $B 4 / 21$ days, $B 5 / 28$ days, $B 6 / 35$ days and $B 7 / 42$ days) each treatment was repeated twice. The observations made were water content, weight loss of banana flour during storage. The results showed that during storage of Kepok Kepok banana flour there was an increase in water content, and weight loss. In the treatment of the use of the type of fabric packaging obtained the highest average water content (9.48\%), which still meets the water content requirements so that microbes do not grow, which is below $14-15 \%$ and meets the water content standard of banana flour according to SNI (01-4447-1998).

Keywords: duration of storage, moisture content, weight loss, banana block

\section{PENDAHULUAN}

Tanaman pisang ( Musa paradisiaca) merupakan tanaman yang banyak tumbuh di daerah tropis dengan varietas yang banyak dan sifat yang bervariasi. Salah satu pisang yang tidak layak dikonsumsi pada kondisi segar adalah pisang kepok gablok (Musa paradisiacal balbisiana). Jenis pisang ini biasa dikonsumsi setelah mengalami pengolahan. Namun sekarang pisang kepok gablok telah mendapat perhatian karena mempunyai kandungan gizi yang tinggi yaitu karbohidrat, vitamin dan 
mineral. Salah satu alternatifnya adalah diolah menjadi tepung. Namun setelah menjadi tepung pisang yang perlu diperhatikan adalah tingkat ketahanan dan keawetan tepung pisang. Selama penyimpanan yang sangat berpengaruh adalah perubahan kadar air dan keberadaan mikroba yang menyebabkan kerusakan pada bahan.

Pengemasan sering juga disebut pembungkusan, pewadahan ataupun pengepakan. Pengemasan mempunyai peranan yang penting dalam mempertahankan mutu suatu bahan pangan (Syarief, 1992). Setiap bahan pangan dirusak oleh mikroba yang berbeda, tergantung pada jenis bahan pangan, kondisi lingkungan dan cara penyimpanan. Misalnya: daging kebanyakan dirusak oleh bakteri, bijibijian kebanyakan dirusak oleh kapang, sari buah kebanyakan dirusak oleh khamir. Keberadaan mikroba dalam bahan makanan sebagian besar akan menimbulkan penyakit, keracunan, kemunduran mutu, dan matinya kehidupan. Hal ini mendorong digunakannya berbagai macam kemasan sebagai bahan pengemas untuk bahan makanan dan minuman. Produk-produk dengan kandungan karbohidrat tinggi seperti tepung merupakan bahan-bahan makanan kering yang sering terkontaminasi seperti jamur, karena kondisi pengemasan maupun penyimpanannya. Selain itu macam kemasan juga akan berpengaruh terhadap kadar air sehingga memungkinkan timbulnya mikroba selama masa simpan.

Tepung pisang kepok gablok merupakan jenis tepung yang mengandung karbohidrat tinggi yang belum diketahui ketahanan tepung yang dikemas dengan menggunakan berbagai macam bahan pengemas karena produk setengah jadi seperti tepung sangat dipengaruhi oleh kadar air. Jumlah air yang terdapat pada bahan pangan akan menyebabkan kerusakan yang disebabkan oleh tumbuhnya mikroba seperti jamur, untuk itu perlu dilakukan penelitian untuk mengetahui pengaruh pengemasan tepung pisang kepok gablok selama penyimpanan.

Penelitian ini bertujuan untuk mengetahui pengaruh lama penyimpanan terhadap kadar air dan pengurangan bobot tepung pisang gablok selama penyimpanan.

Diduga bahwa lama penimpanan akan berpengaruh pada tepung pisang kepok gablok (Musa paradisiacal balbisiana) selama penyimpanan terhadap kadar air, dan susut bobot tepung pisang.

\section{MATERI DAN METODE}

Penelitian dilaksanakan di Laboratium Rekayasa Pangan Teknologi Hasil Pertanian Fakultas Teknologi Pertanian dan Peternakan Universitas Semarang pada bulan Januari 2010 dan Laboratorium Jurusan Teknologi Pengolahan Hasil Pertanian, Fakultas Teknologi Pertanian, Universitas Gadjah Mada pada bulan Pebruari 2010.

Metode penelitian yang digunakan adalah rancangan Acak Lengkap (RAL) dengan dua faktor masing-masing perlakuan dilakukan pengulangan sebanyak dua kali, kemudian diuji lanjut dengan DMRT. Adapun faktor perlakuan adalah sebagai berikut :

\section{Faktor-faktor meliputi:}

B1 : Lama simpan 0 hari

$\mathrm{B} 2$ : Lama simpan 7 hari

B3: Lama simpan 14 hari

B4 : Lama simpan 21 hari

B5 : Lama simpan 28 hari

B6 : Lama simpan 35 hari

B7 : Lama simpan 42 hari

Model matematika yang digunakan adalah sebagai berikut: 


$$
Y_{i j k}=\mu+\beta_{1}+A_{j}+B_{k}+A B_{j k}+\Sigma I_{(j k)}
$$

Dalam hubungan ini :

$Y_{i j k}$ : varibel respon karena pengaruh bersama taraf ke $\mathrm{J}$ faktor $\mathrm{A}$ dan taraf ke $\mathrm{K}$ faktor $\mathrm{B}$ yang terdapat kelompok ke i

$\mu \quad$ : Efek rata-rata yang sebenarnya

$\beta_{1}$ : Efek kelompok ke i

$A_{j}$ : Efek sebenarnya dari taraf ke $\mathrm{J}$ faktor A

$B_{k}$ : Efek sebenarnya dari taraf ke $\mathrm{K}$ faktor B

$A B_{j k}$ : Efek sebenarnya dari interaksi taraf ke $\mathrm{J}$ faktor A dan taraf ke $\mathrm{K}$ faktor B

$\Sigma \mathrm{I}_{(\mathrm{jk})}$ : Efek sebenarnya dari kelompok taraf ke I karena perlakuan (JK)

Pengamatan yang diamati pada penelitian ini adalah kadar air dan susut bobot, menurut (Sudarmadji, 1984), kadar air dihitung dengan perhitungan sbb:

Perhitungan kadar air adalah sebagai berikut :

$$
\text { Susut bobot }=\frac{A-B}{A} \times 100 \%
$$

Keterangan:

1. $X=$ berat botol timbang dikeringkan selama kurang lebih 1 jam dalam oven pada suhu $105 \mathrm{C}$ kemudian dimasukkan dalam eksikator selama 15 menit dan ditimbang beratnya $=(X)$.

2. Timbang sampel yang sudah berupa serbuk dalam botol timbang yang telah diketahui beratnya $(Y)$.

3. Setelah itu timbang sampel yang ada di dalamnya dimasukkan dalam oven dengan suhu $105 \mathrm{C}$ selama 3-5 jam kemudian dimasukkan dalam eksikator selama 15 menit lalu ditimbang, perlakuan tersebut diulang $(Z)$.

4. Dipanaskan lagi dalam oven suhu $105 \mathrm{C}$ selama 30 menit dimasukkan dalam eksikator lalu ditimbang perlakuan tersebut diulang sampai mencapai berat konstan.

Menurut Pantastico, 1976 dalam Nina, 1989, susut bobot ditentukan dengan cara menimbang sampel pada saat pengambilan dari penyimpanan yaitu pada waktu simpan yang ditentukan kehilangan bobot dihitung dengan menggunakan rumus sebagai berikut :

$$
\mathrm{KA}=\frac{\mathrm{X}+\mathrm{Y}-\mathrm{Z}}{\mathrm{Y}} \times 100 \%
$$

$A=$ berat awal penyimpanan, $B=$ bobot pada saat pengambilan setelah waktu simpan yang dibutuhkan.

\section{HASIL DAN PEMBAHASAN}

Dalam penelitian ini diperoleh hasil bahwa pengaruh macam pengemasan terhadap mutu tepung pisang kepok gablok (Musa parasidiaca var balbisiana) selama penyimpanan sebagai berikut:

\section{Kadar Air}

\section{a. Pengaruh lama simpan terhadap kadar air}

Achadijah (1990), produk pangan selama penyimpanan akan mengalami peningkatan kadar air, terutama terjadi pada produk pangan yang bersifat higroskopis menurut Steinkraus (1993) keawetan tepung pisang selama penyimpanan tergantung pada kadar air dan kondisi penyimpanan. Kadar air tepung pisang yang dihasilkan dalam penelitian ini diarahkan pada nilai sekitar 7,65 \% sampai 10,17 sesuai dengan standar tepung $7,6 \%$. Pencapaian kadar air tepung pisang tersebut dapat mempertahankan kualitas sehingga lebih awet disimpan (Muljoharjo, 1998). Terjadinya perubahan kadar air, selama penyimpanan akan sesuai dengan kelembaban nisbi udara sekitar. Permeabilitas pengemas 
tepung pisang menunjukkan gambaran mudah atau tidaknya suatu kemasan untuk ditembus dengan gas, uap, dan cairan. Kenaikan dari kelembaban udara sekitar mengakibatkan laju penetrasi gas terhadap pengemas menjadi tinggi. Perubahan peningkatan rerata kadar air tertinggi terdapat pada perlakuan penyimpanan dan pada pengemasan kain, hal ini disebabkan kain bersifat higroskopis yang tidak mempunyai sifat pelindung terhadap uap air yang ada di udara mudah terserap yang menyebabkan kadar air bahan yang dikemas semakin meningkat.

\section{Analisis Susut Bobot Tepung Pisang}

Berdasarkan analisis ragam diketahui bahwa lama simpan berpengaruh terhadap susut bobot yang dihasilkan. Setelah diuji dengan DMRT diperoleh hasil seperti tertera pada Tabel 2. dimana antar perlakuan berbeda nyata, faktor penggunaan jenis kemasan tepung pisang berbeda nyata, faktor lama simpan berbeda nyata dan terjadi interaksi.

Tabel 2. Rerata Pengaruh Jenis Kemasan dan Lama Simpan Tepung Pisang Terhadap Susut Bobot.

\begin{tabular}{llllllll}
\hline \multirow{2}{*}{$\begin{array}{c}\text { Jenis } \\
\text { kemasan }\end{array}$} & \multicolumn{7}{c}{ Lama Simpan } \\
\cline { 2 - 6 } & \multicolumn{1}{c}{ B1 } & \multicolumn{1}{c}{ B2 } & \multicolumn{1}{c}{ B3 } & \multicolumn{1}{c}{ B4 } & B5 & B6 & Rerata \\
\hline A1 & $52,16^{\text {fgh }}$ & $56,53^{\text {cde }}$ & $59,69^{\text {cde }}$ & $58,25^{\text {bcd }}$ & $60,67^{\text {b }}$ & $68,26^{\text {a }}$ & $59,28^{\text {a }}$ \\
A2 & $50,13^{\text {h }}$ & $49,6^{\text {h }}$ & $50,24^{\text {h }}$ & $51,63^{\text {h }}$ & $50,27^{\text {h }}$ & $54,58^{\text {efg }}$ & $53,15^{\text {b }}$ \\
A3 & $50,14^{\text {h }}$ & $50,65^{\text {h }}$ & $50,67^{\text {gh }}$ & $54,89^{\text {defg }}$ & $56,71^{\text {cde }}$ & $55,83^{\text {de }}$ & $51,08^{\text {c }}$ \\
\hline Rerata & $50,80^{\mathrm{e}}$ & $52,26^{\text {d }}$ & $53,53^{\text {c }}$ & $54,92^{\text {c }}$ & $55,89^{\text {b }}$ & $59,56^{\text {a }}$ & \\
\hline
\end{tabular}

Keterangan :

1. Data kombinasi diikuti dengan superskip huruf yang berbeda, menunjukkan terdapat perbedaan nyata

2. Rerata pada kolom yang diikuti dengan superskip huruf yang berbeda, menunjukkan terdapat perbedaan yang nyata.

3. Rerata pada baris yang sama, yang diikuti dengan superskip huruf yang berbeda, menunjukkan perbedaan yang nyata.

Selama penyimpanan tepung pisang akan mengalami perubahan fisik dan kimia. Perubahan fisik yang terjadi adalah perubahan susut bobot.
Berdasarkan Tabel 2 terlihat susut bobot tepung pisang tergolong kecil. Grafik Peningkatan susut bobot tepung pisang dapat dilihat pada Gambar 2.

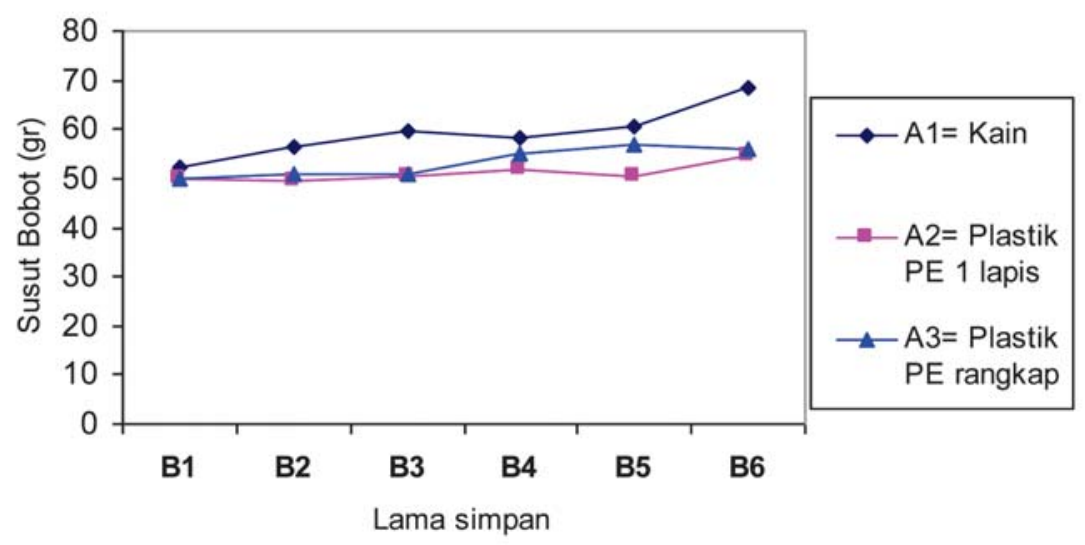

Gambar 2. Grafik Susut Bobot (gr) Tepung Pisang 


\section{a. Pengaruh lama simpan terhadap susut bobot}

Berdasarkan analisis ragam diketahui bahwa lama simpan tepung pisang menunjukan pengaruh nyata $(p<$ $0,05)$ dan setelah di uji dengan DMRT terjadi perbedaan yang nyata pada Gambar 2 terlihat terjadinya perbedaan yang nyata. Pada Gambar 2 setelah terlihat terjadinya kenaikan susut bobot selama penyimpanan kenaikan susut bobot ini dipengaruhi oleh jenis bahan pengemas yang digunakan oleh jenis bahan pengemas yang digunakan, suhu ruang penyimpanan rerata susut bobot tepung pisang selama penyimpanan rerata susut bobot selama penyimpanan menunjukkan peningkatan dari $\mathrm{B}_{2}(52,26$ gr), $B_{3}(55,53 \mathrm{gr}), \mathrm{B}_{4}(54,92 \mathrm{gr}), \mathrm{B}_{5}(55,89)$ dan $B_{6}(59,56 \mathrm{gr})$. Hal ini dipengaruhi karena peningkatan kadar air selama penimpanan semakin meningkat, sehingga kadar air selama penyimpanan dalam tepung pisang yang dikemas juga semakin meningkat.

Peningkatan kadar air yang sebabkan karena proses respirasi dan transpirasi pada bahan menjadi penyebab utama perubahan mutu, karena tidak berpengaruh pada kehilangan kualitas (susut bobot). Tetapi juga menyebabkan kehilangan kualitas (Muchtadi, 1998).

\section{b. Pengaruh jenis kemasan tepung pisang pada lama simpan terhadap susut bobot.}

Berdasarkan hasil analisis ragam antara kedua faktor (jenis kemasan tepung pisang dengan lama simpan) dapat diketahui bahwa penggunaan jenis kemasan tepung pisang yang dihasilkan menunjukkan beda nyata $(p<0,05)$. Setelah diuji dengan DMRT, beda nyata dijumpai pada perlakuan jenis kemasan dan lama simpan.

Naiknya bobot tepung pisang yang dipengaruhi oleh naiknya kadar air tepung pisang selama penyimpanan. Hal ini dipengaruhi karena peningkatan kadar air selama penimpanan semakin meningkat, sehingga kadar air selama penyimpanan dalam tepung pisang yang dikemas juga semakin meningkat. Terjadinya perubahan kadar air, selama penyimpanan akan sesuai dengan kelembaban nisbi udara sekitar.

\section{KESIMPULAN}

Berdasarkan hasil penelitian tentang sifat kimia dan organoleptik tepung pisang dengan penggunaan jenis kemasan selama penyimpanan dapat disimpulkan sebagai berikut:

1. Pengaruh Lama Penyimpanan berdasarkan analisis ragam diketahui bahwa lama simpan berpengaruh terhadap susut bobot yang dihasilkan.

2. Peningkatan kadar air yang sebabkan karena proses respirasi dan transpirasi pada bahan menjadi penyebab utama perubahan mutu, karena tidak berpengaruh pada kehilangan kualitas (susut bobot). Tetapi juga menyebabkan kehilangan kualitas.

3. Berdasarkan hasil analisis ragam pengaruh lama penimpanan terhadap bahan tepung pisang gablok berpengaruh terhadap kualitas tepung pisang gablok.

\section{DAFTAR PUSTAKA}

Anonim, 1984. Profil Industri Kecil Tepung Pisang. Dit Jendral Industri Kecil, Dept. Perindustrian, Jakarta. 
Munadjim, 1988. Teknologi Pengolahan Pisang. Gramedia Jakarta.

Dwijose S, D. 1981. Dasar-Dasar Mikrobiologi. Djambatan, Jakarta.

Fardiaz, S. 1999. Analisis Mikrobiologi Pangan. Petunjuk Laboratorium PAU Pangan dan Gizi IPB Bogor.

Fardiaz, S. 1982. Mikrobiologi Pangan I. Petunjuk Laboratorium PAU Pangan dan Gizi IPB Bogor.

Gaman P. M. dan K.B. Sherington, 1998. Ilmu Pangan : Pengantar IImu Pangan, Nutrisi dan Mikrobiologi. Gadjah Mada University Press UGM.

Indrawati, G, 1986 Pedoman Pratikum Mikrobiologi Dasar, Jurusan Biologi Fakultas M.IPA Universitas Indonesia.

Hadi Oetomo, R.S. 1993. Mikrobiologi Dasar dalam Praktek. Teknik dan Prosedur dasar laboratorium. PT. Gramedia Pustaka Utama, Jakarta.

Jutono, J., Sodarsono, S. Hartadi, Kabirun, Sukardi dan Susanto. 1972. Pedoman Pratikum Mikrobiologi Umum. Untuk Perguruan Tinggi Departemen Mikrobiologi, Fakultas Teknologi Pertanian. UGM, Yogyakarta.

Kuswanto K.R dan S. Sudarmadji, 1988. Proses-proses Mikrobiologi Pangan, Pangan dan Gizi UGM.

Labuza T.P, 1984. Moisture sorption : Pratical Aspect of Isoterm Measuremnt and Use. American Associatin of Cereal Chemist, St. paul Olinnesota.
Matto, A.K., T. Muratio, E. B. Pantastico, K Chachn, dan C T PHan. 1993 Perubahan-Perubahan Kimiawi Selama Pemasakan Dan Penuaan Didalam Er. B, Fantastico, (ed). Fisiologi Pasca Panen. Terjemahan Gadjah Mada University, Yogyakarta.

Muchtadi, T.R. 1989. Pengetahuan Bahan Pangan. PAU Pangan dan Gizi. Institut Pertanian Bogor, Bogor.

Muljo Hardjo, 1998. Blanching and Scalding. Makalah PHP FTP UGM, Yogyakarta.

Munadjim, 1988, Teknologi Pengolahan Pisang, PT. Gramedia, Jakarta.

Purnomo, 1995. Aktivitas Air dan Peranannya dalam Pengawetan Pangan. Ul press, Jakarta.

Rismunandar, 1987. Bertanam Pisang Baru. Algen Sindo, Bandung.

SNI 014447 - 1998. Tepung Pisang. Badan Standarisasi Nasional, Jakarta.

Soewarno, T. S, 1990. Penilaian Organoleptik Untuk Industri Pangan Dan Hasil Pertanian. Bharatara Karya Aksara, Jakarta.

Sri Mulyani dan Soedjono, 1997, Budidaya Pisang, Batara Price.

Sudamoyo, B.1994. Uji Organoleptik. Universitas Diponegoro, Semarang.

Sudarmadji dan Suhardi, 1989, Analisa Bahan Pangan dan Hasil Pertanian Liberty, Yogyakarta.

Syarief, R dan A Irawati, 1988. Pengetahuan Bahan Untuk Industri Pertanian, Mediyatama Sarana Perkasa Jakarta. 
Syarief, R dan H. Halid, 1993 Teknologi Penyimpanan Pangan. Penerbit ARCAN bekerjasama dengan PAU pangan dan Gizi, PB. Bogor.

Soekarta, T. 1985. Penilaian Organoleptik, Penerbit Bharata Karya Aksara, Jakarta.

Wibowo, D. dan Ristanto, 1988. Petunjuk Khusus Deteksi Mikroba Pangan, PAU UGM, Yokyakarta.
Winarno, P.G dan B.S.L. Jenie, 1986. Kerusakan Bahan Pangan dan Cara Pencegahannya, Ghalia Indonesia dan IPB Bogor.

Winarno,F.G. Kimia Pangan dan Gizi, PT. Gramedia Jakarta. 